\title{
MALIGNANT HYPERPYREXIA DURING GENERAL ANAESTHESIA: A REPORT OF TWO CASES
}

\author{
W. G. CuLIEN, M.D., F.F.A.R.C.S."
}

MALIGNANT HYPERPYREXIA or "hyperthermia" occurring during general anaesthesia is sufficiently uncommon in any individual hospital that it is very likely to pass aimost unnoted and unrecorded except in the memory of the anaesthetist and surgeons involved. Recent reports in the literature, however, have made it evident that this complication of general anaesthesia is by no means rare, and that the mortality rate associated with it is extremely high. Since the cause of this lethal complication is, to say the least, obscure, we have considered it important to report the following cases.

\section{CASE I}

The patient was a thin eight-year-old boy weighing 51 lbs. He was presented for appendectomy.

Eight months prior to this admission the child had been anaesthetized with cyclopropane and succinylcholine for splenectomy following traumatic rupture of the spleen. On that occasion preoperative and postoperative fever of $101^{\circ}$ to $102^{\circ} \mathrm{F}$. invoked treatment with penicillin and chloramphenicol. The immediate recovery from the anaesthetic was slow, with recurrent lapse into a drowsy state, but he eventually recovered in spite of several fractured ribs and atelectasis of the lower lobe of the left lung.

On the occasion which is the subject of this report he had a history of fever before admission to hospital. The anaesthetic agent was cyclopropane for induction and maintenance, succinylcholine $20 \mathrm{mg}$. prior to intubation, and 50 c.c. of succinylcholine 0.1 per cent in a drip during operation. The operative diagnosis was acute mesenteric lymphadenitis. Emergence and awakening after the anaesthetic were uneventful. Within an hour the patient became suddenly drowsy, then comatose, and the rectal temperature was $107^{\circ} \mathrm{F}$. Blood and cerebro-spinal fluid taken at this time were negative for bacterial cultures. After a paediatric consultation, penicillin therapy was instigated, and the patient was transferred to the Montreal Children's Hospital. He eventually recovered completely.

\section{CASE II}

This patient was a woman of 32 years of age, married, with two children aged 2 and 5 years, one of which had been born by caesarean section in another hospital. History and physical examination were completely negative.

Height $4^{\prime} 11^{\prime \prime}$. Weight 114 lbs. Blood pressure 124/80.

'Queen Elizabeth Hospital of Montreal. 
This patient was anaesthetized on two occasions, the first being quite uneventful.

\section{Anaesthetic for Diagnostic Dilatation and Curettage and Conization Biopsy of Cervix}

Preoperative medication: demerol $25 \mathrm{mg}$, plus phenergan $25 \mathrm{mg}$. intramuscularly one hour before operation. Good complacent state on arrival in operating room. Agents: (1) 2 per cent thiopental 14 c.c. (280 mg.); (2) oxygen 2 L.; (3) nitrous oxide $2 \mathrm{~L}$.; the last two administered with halothane 0.5 per cent to 2 per cent over 33 minutes.

Technique. Mask and spontaneous respiration. Semi-closed system with absorption. Pulse range 70-80. Systolic blood pressure 115-124. Procedure and recovery uneventful ( 45 minutes).

\section{Anaesthetic for Total Abdominal Hysterectomy}

Preoperative diagnosis: carcinoma in situ of cervix. Operation proposed: total abdominal hysterectomy.

Preoperative state ( 8 weeks after the diagnostic procedure): height $4^{\prime} 11^{\prime \prime}$. Weight 120 lbs. History and physical examination negative, except for above lesion. Chest X-ray negative, temperature normal, E.C.G. negative, pulse 64 per minute, blood and urine negative, blood pressure 145/80, no known allergy. Mild sedation for anxiety (phenobarb gr. 1/4 b.i.d.).

Preoperative medication: demerol $50 \mathrm{mg}$. plus phenergan $25 \mathrm{mg}$. intramuscularly. Drowsy state on arrival in operating room at 7.50 A.M. Agents: (1) 2 per cent thiopental 12 c.c. ( $240 \mathrm{mg}$ ); (2) oxygen $2 \mathrm{~L}$. and (3) nitrous oxide $2 \mathrm{~L}$. both administered together with halothane 1 to 2 per cent; (4) 2 percent succinylcholine 3 c.c. ( $60 \mathrm{mg}$ ) followed by easy intubation with Magill red rubber tube with built-in cuff, which was inflated; (5) succinylcholine drip 0.1 per cent, 500 c.c. over 70 minutes; (6) $\mathrm{O}_{2}$ plus $\mathrm{N}_{2} \mathrm{O}$ plus halothane as above for 75 minutes.

Technique. Semi-closed with absorption, automatically controlled ventilation using Bennett respirator. Canadian Oxygen Company gas machine with Fluotec halothane vaporizer Mark II.

From 8.00 to 9.00 A.M. the anaesthetic was uneventful, there being no unusual responses to the agents used except that the pressure on the ventilator required to produce good ventilation (i.e. 700 c.c. tidal volume) was about $25 \mathrm{~cm}$. of water. Additional amounts of muscle relaxant had no apparent effect on the required ventilating pressure.

Good surgical conditions were readily provided and the procedure was almost completed within the first hour. Just before the abdominal closure was begun, it was noted simultaneously that the face and neck of the patient were flushed and sweating profusely as the pulse suddenly climbed from 80 to 100 , and that the systolic blood pressure rose from 140 to $190 \mathrm{~mm}$. Hg. At this time, there was further discussion about the necessarily high inflation pressure; it was so high that the cause was suspected to be some mechanical obstruction, e.g. distortion of the inflated cuff. 
From then on the course of events was as follows.

9.15 A.M. Halothane turned off. Pulse 130 systolic. Blood pressure $205 \mathrm{~mm}$. Hg.

9.50 A.M. Operation finished, drapes removed etc. Patient sweating. Rectal temperature $103.6^{\circ} \mathrm{F}$., pulse 130 , systolic blood pressure $220 \mathrm{~mm}$. Hg. Orotracheal tube changed from Magill red rubber to Portex $8 \mathrm{~mm}$. (I.D.) with cuff.

10.00 A.M. Since soda lime double canisters were both very hot, the whole gas machine was replaced with a new cool unit. There was no apparent change in the ventilation pressure required.

10.20 A.M. With systolic blood pressure at $240 \mathrm{~mm}$. $\mathrm{Hg}, 2.5 \mathrm{mg}$. reserpine was given intramuscularly, as recommended by two medical consultants.

10.30 A.M. Direct ice cooling was started as well as chilled intravenous solution of 5 per cent dextrose in water. Thermocouple recording thermometer was placed in the rectum for a continuous visual record. E.C.G. monitoring was established. Gas flows were increased to oxygen $5 \mathrm{~L}$. plus nitrous oxide $5 \mathrm{~L}$. with continued automatic control of ventilation. Then oxygen to $10 \mathrm{~L}$. Levin tube was placed in stomach to drain old blood-coloured liquid. Profuse brown watery diarrhoea began and recurrently was bright red and very profuse over the whole postoperative period.

11.05 A.M. Blood pressure was now 210. It continued to fall until it was 80 systolic and the pulse was 160 and very weak. Temperature $109.5^{\circ} \mathrm{F}$.

11.20 A.M. Temperature $108^{\circ} \mathrm{F}$. Patient took a big deep breath several times, but only by request.

11.30 A.M. Temperature $107^{\circ} \mathrm{F}$.

12.05 A.M. Vertical nystagmus with spasmodic eyelid and head movements. Pupils reacting to light (?). Temperature $104^{\circ} \mathrm{F}$.

12.25 P.M. Pulse varying in rate and strength.

12.50 P.M. Shivering, eyes widely open, moving left leg, coughing. Temperature $102^{\circ} \mathrm{F}$.

1.05 P.M. Ten c.c. blood withdrawn from external jugular vein for blood gas analysis. Temperature $100^{\circ} \mathrm{F}$.

1.25 P.M. Moving both legs. Blood samples taken for culture.

1.30 P.M. Ventilator off. Adequate spontaneous ventilation.

1.35 P.M. Mannitol test dose 300 c.c. in 10 per cent solution given in 8 minutes.

1.45 P.M. Responding to verbal stimuli. Breathing well and extubated.

1.50 P.M. To recovery room. Temperature $98^{\circ} \mathrm{F}$.

Recovery room. Responding to painful stimuli. Skin colour good but lips cyanosed. Cool to touch. Dressing dry. Scant sanguinous vaginal discharge. Foley catheter draining amber urine. Oxygen at $6 \mathrm{~L} . / \mathrm{min}$. started by nasal catheter. Respiration laboured. Pupils reacting to light, appear equal. Left pupil slower to react.

2.00 P.M. to 2.20 P.M. Sodium bicarbonate solution (Baxter) 500 c.c. (mEq. 300 ) intravenously.

2.10 P.M. Colour mottled. Extremities very cold. Respiration laboured and shallow. Nailbeds cyanosed. 
2.15 P.M. Pupils equal and reacting to light. Large amount of brownish liquid with blood appearing to be from rectum.

2.50 P.M. Left pupil larger than right.

3.20 P.M. Urine specimen to lab. for haemoglobin. Blood taken for haemoglobin, haematocrit, coagulogram. Stomach secretions to lab. for haemoglobin. Intravenous Solucortef $250 \mathrm{mg}$.

4.20 P.M. No blood pressure recordable by stethoscope or oscillation methods. Pulse thready at 132 .

4.30 P.M. Still no blood pressure. Methedrine $4 \mathrm{mg}$. intravenous. Pupils not reacting to light. Breathing poorly. Patient put in Trendelenburg position. Intubated and put on Bennett Respirator. Colour very mottled. Suctioned for moderate amount of bright sanguinous drainage.

4.50 P.M. Pulse very rapid.

5.00 P.M. Breathing spontaneously. Taken off respirator. Oxygen at $6 \mathrm{~L} . / \mathrm{min}$.

5.20 P.M. Pulse 150. Incontinent of faeces. Feet and hands very mottled. Still no recordable blood pressure.

5.30 P.M. Patient shivering violently. Very stiff. Feet turning in.

6.00 P.M. Rheomacrodex in normal saline $500 \mathrm{ml}$. added. Patient perspiring.

6.20 P.M. to 6.40 P.M. Sodium bicarbonate solution (Baxter) 250 c.c. (mEq. 150) intravenously. Condition of patient deteriorating steadily. Temperature rising again.

1.30 A.M. Lumbar puncture done. Three specimens of clear fluid sent to lab.

2.00 A.M. Patient pronounced dead.

\section{LABORATORY TESTS}

1. Blood gases

\begin{tabular}{|c|c|c|c|c|}
\hline & \multicolumn{4}{|c|}{ Venous Blood Drawn } \\
\hline & 1.15 P.M. & 2.45 P.M. & 6.00 P.M. & 8.30 P.M \\
\hline $\begin{array}{l}\text { Actual pH } \\
\text { Actual } \mathrm{PcO}_{2} \text { (mm.Hg) } \\
\text { Base excess (mEq./L. blood) } \\
\text { Buffer base (mEq./L. blood) } \\
\text { Standard bicarb (mEq./L.plasma) } \\
\text { Actual bicarb (mEq./L. plasma) } \\
\text { Total } \mathrm{CO}_{2} \\
\mathrm{CO}_{2} \text { dissolved (mEq./L.) } \\
\mathrm{HCO}_{3} / \mathrm{H}_{2} \mathrm{CO}_{3} \text { ratio }\end{array}$ & $\begin{array}{c}7.175 \\
31.0 \\
-17.1 \\
33.5 \\
12.9 \\
10.9 \\
0.93 \\
11.7\end{array}$ & $\begin{array}{l}7.352 \\
45.5 \\
-1.0 \\
47.0 \\
23.0 \\
24.6 \\
25.9 \\
1.36 \\
18.1\end{array}$ & $\begin{array}{l}7.30 \\
54.5 \\
-2.5 \\
50.1 \\
22.1 \\
26.0 \\
27.6 \\
1.64 \\
15.9\end{array}$ & $\begin{aligned} 7.35 \\
54.0 \\
+13.0 \\
74.0 \\
36.2 \\
44.0 \\
45.6 \\
1.62 \\
27.1\end{aligned}$ \\
\hline
\end{tabular}

2. Stomach content: positive for blood.

3. Urine: positive for haemoglobin.

4. Coagulogram: normal except prothrombin $=21$ seconds (control $13 \mathrm{sec}$.).

5. Electrolytes (mEq./L.): Blood drawn at 8.30 P.M. $\mathrm{K}=3.1, \mathrm{Na}=147$, $\mathrm{Cl}=90$.

6. Lumbar puncture (terminal state): C.S.F. -3 samples crystal clear; less than

1 R.B.C./cu. mm.; less than 1 W.B.C./cu. mm.

7. Stool culture: negative.

8. Blood culture: negative; blood drawn at 1.25 P.M. 
9. Intravenous drugs and solutions all cultured. (a) $2 / 3$ and $1 / 3$ solution $(2 / 3$ of $5 \%$ dextrose $3.3 \mathrm{gm} . / 100$ c.c., $1 / 3$ of normal saline $0.3 \mathrm{gm} . / 100$ c.c.); (b) $2 / 3$ and $1 / 3$ plus Anectine 0.1 per cent; $(c)$ Thiopental 2.0 per cent; (d) Anectine 2.0 per cent. Results: all results negative, after four days, for aerobic and anaerobic organisms.

10. Halothane studies. Halothane analysis fulfilled all British Pharmacopoeial Standards except for colour, which was due to thymol (preservative). The presence of the latter is not significant as a toxic factor.

Consultations were obtained from several internists, a neurologist, and a gynaecologist, as well as members of the anaesthesia departments at the Queen Elizabeth Hospital and the Montreal Children's Hospital.

\section{Treatment}

1. Hypothermia: cooling with $(a)$ ice packs, $(b)$ cold solutions intravenously.

2. Alkalinization: sodium bicarbonate solution (Baxter) $595 \mathrm{mEq} . / \mathrm{L}$., administered intravenously; (a) from 2.00 P.M. to 2.20 P.M., 500 c.c. ( $300 \mathrm{mEq}$.); (b) from 6.20 P.M. to 6.40 P.M., 250 c.c. (150 mEq.); total $450 \mathrm{mEq}$. (approx.).

3. Mannitol: from 1.00 P.M. to 10.00 P.M. a good response was obtained from 1000 c.c. of 10 per cent Mannitol solution.

4. Steroids: Solucortef $250 \mathrm{mg}$. at 3.30 P.M., and $250 \mathrm{mg}$. added to each 1000 c.c. of Lactate Ringer's solution. Total dose, $1000 \mathrm{mg}$. Solucortef.

5. Other intravenous solutions: (a) blood 500 c.c.; (b) Rheomacrodex in normal saline 500 c.c.

6. No antibiotic drugs.

\section{AUTOPSY RePorT}

At autopsy there were early degenerative changes in cerebral and cerebellar cortical and hypothalamic neurons; focal (centrilobular) necrosis in the liver; fresh haemorrhage into the gastro-intestinal tract; acute congestion of the mucous membranes of the gastro-intestinal tract, trachea, and urinary bladder; acute congestion of renal capillaries; cloudy swelling and mild vacuolation of the renal tubular epithelium, and mild pulmonary emphysema with mild intra-alveolar haemorrhages.

There was no evidence of a distinct primary lesion, such as haemorrhage or embolism, in the hypothalamus or elsewhere in the brain, and the degenerative changes found can be attributed to the effects of hyperthermia, anoxia, etc.

\section{Final Diagnosis}

Carcinoma in situ of the cervix.

Early degenerative changes in cerebral and cerebellar cortical neurons (secondary to anoxia and hyperthermia).

Focal (centrilobular) necrosis of liver.

Gastro-intestinal haemorrhage (unchanged blood from stomach to rectum). Acute congestion of stomach and small intestines, trachea, and bladder.

Cloudy swelling of kidneys. 
Mild acute emphysema of lungs.

Surgical absence of uterus.

Surgical absence of gallbladder.

\section{Drscussion}

Although the high fever was reduced to even subnormal levels and the marked acidosis was corrected, the damage produced by such extreme hyperthermia was apparently irreparable. Whether the use of heavy antibiotic therapy would have altered the course in this case cannot be answered. However, the finding of negative cultures from both blood and the solutions used in the treatment seems to rule out any question of infection due to contaminated solutions. Recently it was reported ${ }^{1}$ that solutions contaminated with "alcaligenes faecalis" produced several cases of hyperthermia during and after anaesthetics. In these cases antibiotic drugs provided effective therapy.

\section{Comment}

Our two cases of extreme hyperthermia during and after anaesthetics had the following factors in common:

1. The patients were thin, and of small body build.

2. Succinylcholine was given to both for intubation and maintenance.

3. Peak rectal temperature was at least $107^{\circ} \mathrm{F}$.

4. Blood cultures were negative.

5. Cause of the unexpected hyperthermia still remains completely obscure.

6. Succinylcholine and the other agents appeared to produce no other unusual responses in the patients, such as prolonged fasciculations or spastic muscles.

\section{RÉSUMÉ}

Nous rapportons deux cas d'hyperpyrexie maligne ou "d'hyperthermie" survenus au cours d'une anesthésie générale.

Le premier malade, un garçon maigre de 8 ans pesant 51 livres, s'est présenté pour appendicectomie. Huit mois avant cette admission, il avait subi une anesthésie au cyclopropane avec succinylcholine pour une splénectomie; à la suite de cette opération une fièvre de $102^{\circ} \mathrm{F}$. avait été traitée par de la pénicilline et du chloramphenicol. Cette fois-ci, on racontait une histoire de fièvre avant son admission à l'hôpital. Nous avons employé, cette fois-ci, comme agent anesthésique: le cyclopropane; nous avons produit le relachement musculaire pour l'intubation avec $20 \mathrm{mg}$. de succinylcholine et, au cours de l'opération, avons utilisé $50 \mathrm{ml}$. de succinylcholine en goutte à goutte en solution à 0.1 pour cent. Le diagnostic opératoire a été lymphadénite mésentérique aiguë. L'élimination de l'anesthésie et le réveil ont été sans évènements remarquables mais, en deça d'une heure, le malade est devenu subitement sommeillant, puis comateux et sa température rectale a atteint $107^{\circ} \mathrm{F}$. Les cultures du sang et du liquide céphalorachidien ont été négatives. On a commencé une thérapie à la pénicilline et le malade a récupéré complètement.

La deuxième malade est une femme de 32 ans. Son histoire et son examen 
physique sont tout à fait négatifs. Antérieurement, dans un autre hôpital, elle avait subi une anesthésie sans incident pour une césarienne: puis, huit semaines avant cette admission, elle avait subi une anesthésie pour dilatation, curettage et biopsie du col utérin. On a employé alors pour l'anesthésie du thiopentone, du protoxyde d'azote et de l'oxygène et de l'halothane. Huit semaines plus tard, elle était admise de nouveau pour hystérectomie totale. L'examen physique et les analyses de laboratoire n'ont rien révélé de positif. Elle prenait un léger sédatif pour calmer son anxiété: phenobarbital $1 / 4$ gr. deux fois pour jour.

Sa prémédication a consisté en: démérol $50 \mathrm{mg}$. et phénergan $25 \mathrm{mg}$. en injection intramusculaire. A son arrivée à la salle d'opération elle était sommeillante; l'anesthésie a été faite avec du thiopentone $240 \mathrm{mg}$. du protoxyde d'azote et de l'oxygène et de l'halothane; pour l'intubation, nous avons donné $60 \mathrm{mg}$. de succinylcholine; nous avons mis en place un tube magill avec ballonnet; celui-ci a été gonflé. Au cours des 75 minutes qu'a duré l'opération elle a reçu $500 \mathrm{ml}$. d'une solution de succinylcholine a 0.1 pour cent. Durant ce temps, nous avons fait le maintien de l'anesthésie avec du protoxyde d'azote, de l'oxygène et de l'halothane. Nous avons employé un circuit semi-fermé avec absorption et une ventilation controlée automatiquement.

Nous avons donné une bonne anesthésie chirurgicale et l'opération était presque terminée lorsque nous avons observé simultanément que la face et le cou étaient conjestionnés, qu'elle transpirait profusément, que son pouls soudainement était passé de 80 à 100 d̀ la minute et sa pression systolique, de 140 à $190 \mathrm{~mm}$. Hg. La pression à l'inspiration nous a semblé plus élevée qu'elle n'aurait dû l'être. Nous avons pensé qu'il devait s'agir d'une obstruction quelconque dans les voies respiratoires. Le pouls et la pression ont continué à s'élever et, à la fin de l'opération, la température rectale était de $103.6^{\circ} \mathrm{F}$.

Nous avons commencé le refroidissement direct avec de la glace et avons administré des solutions froides par voie endoveineuse. Nous avons continué la ventilation avec de l'oxygène et du protoxyde d'azote. Malgré ces soins, trois heures après l'induction, la température de la malade avait atteint $109.5^{\circ} \mathrm{F}$, mais plus tard, graduellement, elle s'est abaissée à des niveaux normaux. La malade a présenté une diarrhée sanglante et, par le tube de Levine, on a retiré du sang. Malgré nos efforts pour contrôler la température et pour traiter l'acidose métabolique, l'état de la malade s'est détérioré et, dix-huit heures après l'induction, elle mourait. Les analyses de laboratoire, les traitements, les constatations à l'autopsie sont détaillés dans le rapport.

\section{REFERENCE}

1. Model, Jerome H. Septicemia as a Cause of Immediate Postoperative Hyperthermia. Anesthesiology. 27: 329 (1966). 